The writer spent the summer in the new area and travelled throughout much of the region from Frederikshåbs Isblink up to Fiskenæsfjorden. The main object was to learn as much as possible about the geology and problems of access and supply to facilitate planning of future work. Much of the western part of the area has been mapped in reconnaissance form by B. F. Windley, and the writer had the benefit of having photographic copies of Windley's maps. Some of the coast sections were re-examined and a few areas were mapped in detail.

The western part of the area is covered by good topographic maps at a scale of $1: 20000$. The only maps available in the eastern part of the area are at a scale of $1: 250000$. After a summer in the field it became clear that it would be desirable to map the whole area on base maps at a scale of 1:20 000. GGU therefore approached a private firm to find out whether it would be possible to produce acceptable base maps using available vertical aerial photography and existing point control. The firm is at present working on a trial strip, and if this is a success the work will be extended to cover the whole of the area where 1:20000 maps are lacking at present.

On the basis of what is known of the regional geology and on the basis of the topography, the region between Frederikshåbs Isblink and the fjord system south of the base, but excluding for the time being the area south-east of the innermost part of Fiskenæsfjorden, has been divided into nine areas, each about $250 \mathrm{~km}^{2}$, for mapping. Each area will be for one geologist with an assistant and will be for two summers.

In addition to the nine mapping teams, one geologist will be in the area to make a special study of the sapphirine-bearing rocks. It is also probable that GGU will be supporting surveyors from the Geodetic Institute and an entomologist making a study of the small black flies (Simulium) with a view to finding a method for reducing their number locally.

Two helicopters will be stationed at the base during the summer and will be available for reconnaissance work and for checking of areas mapped, as well as for moving camps. GGU will also have ships in the area for work in coastal waters.

The 1970 field season will start in mid-June and continue until the end of August.

\title{
BASIC ROCKS OF THE GARDAR IGNEOUS PROVINCE
}

\section{B. G. J. Upton}

The mapping of south-west Greenland by the GGU to a scale of $1: 20000$ has revealed a profusion of unmetamorphosed dolerite dykes within the Precambrian basement. Although obviously younger than the latest regional metamorphic event, these basic rocks are either older than, or approximately contemporaneous with, such central igneous complexes as Ilímaussaq and Kûngnât, and it is now clear that basic mag- 
matism played a major role in the evolution of the Gardar alkaline province of which these complexes form a part. This is further attested by the preservation of basaltic lavas within the region, particularly within the down-faulted block of the Ilimaussaq peninsula. The basic intrusions and lavas are believed to be between 1400 and 1000 m. y. old.

However, in spite of, or perhaps because of, their very ubiquity, the dolerites and gabbros appear to have been sampled and investigated far less assiduously than the associated syenites and granites. To redress this imbalance, these rocks were sampled as widely as possible in July and August 1969 , between $60^{\circ} 30^{\prime}$ and $61^{\circ} 30^{\prime} \mathrm{N}$ and $45^{\circ} 15^{\prime}$ and $48^{\circ} 45^{\prime} \mathrm{W}$.

One of the earliest manifestations of basaltic volcanism after Sanerutian (lateKetilidian) plutonism, was the emplacement of roughly WSW trending dolerite dykes up to $100 \mathrm{~m}$ broad. This swarm of $\mathrm{BD}_{0} \mathrm{~s}$ (i. e. "brown dykes, generation zero") extends over a belt of more than $120 \mathrm{~km}$ across and can be traced for over $200 \mathrm{~km}$.

Subsequent dykes were intruded predominantly along directions between NE and ENE. The zones in which these later dykes reach their greatest concentration are, from ESE to WNW (a) the Narssarssuaq-Tugtutôq zone (b) the Nunarssuit-Isortoq zone, and rather more diffusely (c) the Ivigtut zone. Dolerite dykes to which Gardar ages have been ascribed outcrop over a considerably wider region but it is these zones of more intense activity, coinciding with the areas in which the principal alkaline igneous complexes occur, that have been selected for further study.

In the Narssarssuaq-Tugtutôq zone, the earliest of the ENE dykes include the largest as well as the most basic members. In other words it may be that at this stage that magma temperatures were highest and that Gardar volcanism was at its most energetic. A $500 \mathrm{~m}$ wide composite dyke of ferro-syenogabbro with a nepheline syenite central component was followed by the emplacement of massive dykes of olivine dolerite/gabbro, extending up to $800 \mathrm{~m}$ width and traceable (intermittently because of lack of outcrop and younger cross-cutting intrusives) over $120 \mathrm{~km}$ from the Julianehåb Bugt to the Inland Ice. The gabbros and dolerites comprising these dykes are relatively iron-rich and troctolitic (Upton, 1964). In their highest structural levels seen in the vicinity of Narssaq, they contain abundant inclusions of coarsegrained anorthosite. On Tugtutôq, one of these massive dykes displays a composite nature with emplacement of first, syenogabbro and later, quartz syenite along its central part.

Thin flows of basaltic lavas, commonly with radial aggregates of plagioclase phenocrysts and (pseudomorphed) olivine phenocrysts, are typical of the Ipiutaq Volcanit Unit and the lower basalts of the stratigraphically higher Ilimaussaq Volcanic Unit within the Eriksfjord Formation lavas and sediments of the Ilimaussaq peninsula (Stewart, 1964). These particular lavas have compositional affinities with the large ENE dolerite/gabbro dykes and were probably erupted from shield-volcanoes along their surface outcrop. Flow features (particularly ropy surfaces and pipeamygdales), at least in the Ipiutaq Volcanic Unit, indicate derivation from a northerly 
source and it is suggested that they were erupted from one or more of the dykes now covered by the waters of Bredefjord, to the north of the Ilimaussaq peninsula.

Subsequent basic dykes in this zone appear to be either trachybasaltic or still more differentiated. The most striking of these swarms is that involving the "big feldspar dykes" (Bridgwater \& Harry, 1968), noteworthy for their high contents of anorthositic inclusions.

What may well be the latest of the ENE dyke swarms in this area (post-dating most, if not all of the tracytes, phonolites and rhyolites) is a swarm of strongly flowbanded trachybasaltic dykes characterised by the presence of ocelli containing feldspar, calcite, epidote or chlorite, either alone or in combination. The one available analysis of a member of this swarm shows a $\mathrm{K} / \mathrm{Na}(\mathrm{wt} \%)$ ratio of 1.5:1 and it is possible that the whole swarm displays a similar strongly potassic nature.

Ultrabasic magmas of monchiquitic and carbonatitic affinities were erupted on a small scale early in Gardar times in the Narssarssuaq area (Stewart, in press, and Walton, 1965). The age of these relative to the $\mathrm{BD}_{0} \mathrm{~s}$ is unknown but they were almost certainly earlier than the large ENE dykes. However, in the Narssaq region comparable monchiquitic magmas were erupted in minor intrusives, after the emplacement of the large dykes.

In the Nunarssuit-Isortoq zone, Harry \& Pulvertaft (1963) have recognised five swarms of dykes, principally of dolerite or gabbro. The earliest $\left(\mathrm{BD}_{0}\right)$ swarm is cut by $\mathrm{N}$ or NNE dolerite dykes which are themselves earlier than dykes intruded along NE or ENE trends. Ultrabasic intrusions comparable to those of the Narssarssuaq or Narssaq areas are apparently absent from this zone where the pattern has essentially been one of repetitive intrusion of basaltic magma. Many of the basic dykes carry plagioclase megacrysts or anorthosite inclusions. Synformally layered gabbroic dykes, similar in width and composition to those of the Tugtutô-Narssarssuaq zone, occur among the ENE trending swarms. The resemblance between the ENE dykes of the two zones is enhanced by the presence of large composite dykes with broad syenitic or syenogabbroic central units (Bridgwater \& Coe, in press). One large composite gabbro/quartz syenite body in the vicinity of Bangs Havn shows particularly close similarity to the complexes of Assorutit and Narssaq in the more southerly zone.

In the Ivigtut region olivine-rich lamprophyric dykes are among the earliest of the ENE and NE swarms and are believed to pre-date the $\mathrm{BD}_{0} \mathrm{~s}$. As in the NunarssuitIsortoq zone, the $\mathrm{BD}_{0} \mathrm{~s}$ were followed by several episodes of basaltic intrusion, principally in the NE and ENE trending dyke swarms. Composite dykes are rare in this region and even the largest dykes have simple, non-accumulitic, internal structures. Probably the youngest manifestation of Gardar basaltic eruption in the area is the gabbroic ring-dyke cutting the syenites of the Kûngnât complex.

Apart from the Kûngnât occurrence, basic rocks also occur in the form of narrow ring-dykes in the Motzfeldt and Igdlerfigssalik centres in the east of the province (Emeleus \& Harry, in press). Relics of what may formerly have been substantial 
layered gabbroic complexes associated with the ENE dyke swarms are found at Alángorssuaq and Bangs. Havn, both in the Nunarssuit area (Harry \& Pulvertaft, 1963), and at Narssaq. Since in each case these gabbroic masses have been intruded by younger alkaline complexes, their original extent is a matter of speculation.

Some fifty analyses and partial analyses of Gardar basic rocks are available from which some broad generalisations can be made. Firstly, what may be described as "primitive" basaltic compositions with over $7.5 \% \mathrm{MgO}$ and less than $1 \% \mathrm{~K}_{2} \mathrm{O}$ are rare and were probably never erupted in any quantity. Whereas $\mathrm{MgO}$ contents rise as high as $20 \%$ in some of the ultrabasic (lamprophyric) rocks, the majority of doleritic and gabbroic dykes rocks have contents between 10-4\%, corresponding to silica contents of between 42 and $48 \%$. The basic rocks have characteristically high iron contents $\left(\mathrm{Fe}_{2} \mathrm{O}_{3}+\mathrm{FeO}>12 \%\right)$ and also relatively high contents of the so-called incompatible elements $\left(\mathrm{K}_{2} \mathrm{O}\right.$ typically $\left.>1 \%\right)$. These data suggest that the Gardar volcanism in south Greenland may have brought about a highly selective depletion of the upper mantle in its lowest melting constituents.

Alumina contents of the basalts, dolerites and gabbros tend also to be high (generally $>14 \%$ ) which accords with the widespread occurrence of plagioclase phenocrysts in the lavas and chilled facies of intrusives and the frequent occurrence of xenoliths and xenocrysts of anorthositic materials. The corresponding scarcity of pyroxene as phenocrysts throughout the basic rocks of the province is also noteworthy.

It is hoped that a more careful discrimination between the chemical characteristics of the different swarms, both in space and time, in south Greenland may provide a framework for comparisons with the roughly contemporaneous basic rocks of Labrador and Sweden.

\section{References}

Bridgwater, D. \& Harry, W. T. 1968: Anorthositic xenoliths and plagioclase megacrysts in Precambrian intrusions of South Greenland. Bull. Gronlands geol. Unders. 77 (also Meddr Gronland 185, 2).

Bridgwater, D. \& Coe, K. in press: The part played by stoping in the emplacement of certain giant syenogabbro dykes. Geol. J.

Emeleus. C. H. \& Harry, W. T. in press: The Igaliko nepheline syenite complex. General description. Bull. Gronlands geol. Unders. (also Meddr Gronland 186, 3).

Harry, W. T. \& Pulvertaft, T. C. R. 1963: The Nunarssuit intrusive complex, South Greenland, Part I. General description. Bull. Gronlands geol. Unders. 36 (also Meddr Gronland 169, 1).

Stewart, J. W. 1964: The earlier Gardar igneous rocks of the Ilimaussaq area, South Greenland. Unpublished Ph. D. thesis, Durham.

Stewart, J. W. in press: Precambrian alkaline-ultramafic/carbonatite volcanism at Qagssiarssuk, South Greenland. Bull. Gronlands geol. Unders. (also Meddr Gronland 186, 4).

Upton, B. G. J. 1964: The geology of Tugtutôq and neighbouring islands, South Greenland. Part III. Olivine gabbros, syeno-gabbros and anorthosites. Bull. Grønlands geol. Unders. 48, 1-47 (also Meddr Grenland 169, 3).

Walton, B. 1965: Sanerutian appinitic rocks and Gardar dykes and diatremes, north of Narssarssuaq, South Greenland. Bull. Gronlands geol. Unders. 57 (also Meddr Grønland 179, 9). 